\title{
Digital Health and Inequalities in Access to Health Services in Bangladesh: Mixed Methods Study
}

Tanvir Ahmed ${ }^{1,2}$, MBBS, MPH; Syed Jafar Raza Rizvi ${ }^{3}$, BSc, MSc; Sabrina Rasheed ${ }^{4}$, PhD; Mohammad Iqbal ${ }^{5}$, MBBS; Abbas Bhuiya ${ }^{4}$, PhD; Hilary Standing ${ }^{1}$, PhD; Gerald Bloom ${ }^{1}$, BPhil, MDCM; Linda Waldman ${ }^{1}, \mathrm{PhD}$

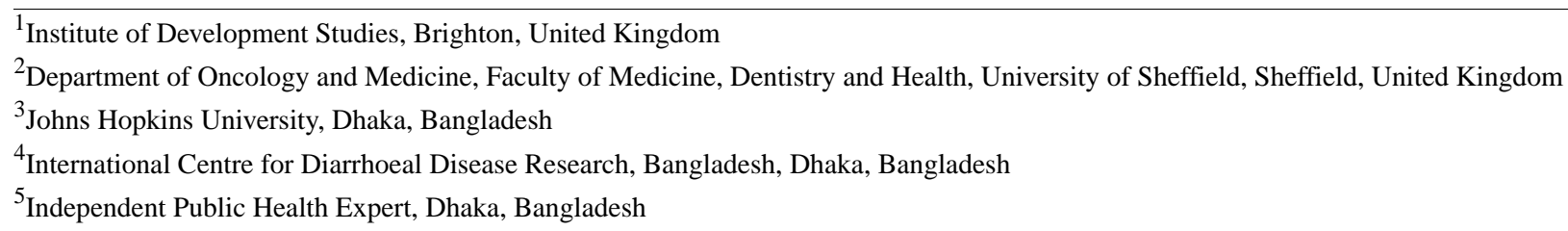

Corresponding Author:

Tanvir Ahmed, MBBS, MPH

Department of Oncology and Medicine

Faculty of Medicine, Dentistry and Health

University of Sheffield

Jessop Wing Maternity Unit

Tree Root Walk, Broomhall

Sheffield, S10 2SF

United Kingdom

Phone: 447931163982

Email: tanvir79@outlook.com

\begin{abstract}
Background: Globally, the rapid growth of technology and its use as a development solution has generated much interest in digital health. In line with global trends, Bangladesh is also integrating technology into its health system to address disparities. Strong political endorsement and uptake of digital platforms by the government has influenced the rapid proliferation of such initiatives in the country. This paper aims to examine the implications of digital health on access to health care in Bangladesh, considering who uses electronic devices to access health information and services and why.
\end{abstract}

Objective: This study aims to understand how access to health care and related information through electronic means (digital health) is affected by sociodemographic determinants (ie, age, gender, education, socioeconomic status, and personal and household ownership of mobile phones) in a semiurban community in Bangladesh.

Methods: A cross-sectional survey of 854 households (between October 2013 and February 2014) and 20 focus group discussions (between February 2017 and March 2017) were conducted to understand (1) who owns electronic devices; (2) who, among the owners, uses these to access health information and services and why; (3) the awareness of electronic sources of health information; and (4) the role of intermediaries (family members or peers who helped to look for health information using electronic devices).

Results: A total of $90.3 \%$ (771/854) of households (471/854, 55.2\% of respondents) owned electronic devices, mostly mobile phones. Among these, $7.2 \%$ (34/471) used them to access health information or services. Middle-aged (35-54 years), female, less (or not) educated, and poorer people used these devices the least $(\alpha=.05, \alpha$ is the level of significance). The lack of awareness, discomfort, differences with regular care-seeking habits, lack of understanding and skills, and proximity to a health facility were the main reasons for not using devices to access digital health.

Conclusions: Although influenced by sociodemographic traits, access to digital health is not merely related to device ownership and technical skill. Rather, it is a combination of general health literacy, phone ownership, material resources, and technical skill as well as social recognition of health needs and inequity. This study's findings should serve as a basis for better integrating technology within the health system and ensuring equitable access to health care.

(JMIR Mhealth Uhealth 2020;8(7):e16473) doi: 10.2196/16473 


\section{KEYWORDS}

health equity; eHealth; mHealth; digital health; health technology; Bangladesh; developing countries

\section{Introduction}

\section{Background}

Globally, there has been an impressive growth in the number of cell phones and internet users, and the price of services and devices has decreased [1,2]. Mobile phones have become a thriving market, characterized by 7.7 billion (estimated) subscribers in 2017. Globally, the proportion of the population covered by at least a second generation $(2 \mathrm{G})$ network grew from $58 \%$ in 2001 to $95 \%$ in 2015 . Internet penetration grew from $6.5 \%$ in 2000 to $43 \%$ in 2015 , and the proportion of households with internet access at home increased from $18 \%$ in 2005 to $46 \%$ in $2015[3,4]$. The mobile-cellular subscription per 100 inhabitants has exceeded $100 \%$ in developed countries, and both developing and least developed countries (LDCs) are racing toward similar levels. Since 2005, most subscriptions have come from developing countries and LDCs, and the gap between these and developed countries is reducing (Figure 1) [3].

According to the International Telecommunication Union, a $10 \%$ increase in internet speed can increase economic growth by $1.3 \%$ in low- and middle-income countries (LMICs) $[5,6]$. Given such growth and potential, both national and personal spheres are now influenced by digital innovations, as governments strategize to expand coverage of developmental initiatives by reaching remote areas or individuals who engage in web-based shopping or personal banking. In 2014, the mobile-cellular industry generated US \$3 trillion, which contributed to $3.8 \%$ of the global gross domestic product, and this number is expected to rise to $4.2 \%$ by 2020 [7]. This economic contribution came about largely by linking previously unconnected communities, financial inclusion through eCommerce (use of electronic means including mobile phones for financial purposes such as transferring money, everyday banking etc), and designing and delivering innovative solutions for improving quality of life (eg, sharing information, providing services, technologies for mass production). Examples include Tigo Kilimo by Tigo in Tanzania (launched in 2013) [7] and Airtel Green SIM in India (launched in 2007) for eAgriculture (use of electronic means including mobile phones to provide and access information regarding farming techniques and related products and market) [8,9] and TradeNet in Ghana [10] and bKash in Bangladesh [11,12] for eCommerce and mCommerce (using technology including mobile phones for financial transactions) as mobile wallets. M-Pesa by Vodafone is one of the largest mobile-based financial services in the world, used by millions across Africa, Europe, and Asia [13-15]. The information and communications technology (ICT) industry is now a popular area for employment worldwide. In 2014, the mobile industry directly employed approximately 13 million people and indirectly supported 12 million more [7,16-18]. Similar to other development domains, health is also exploring the potential of technology in improving the well-being of people, including health-related well-being, which can range from improvement in health ailments to acquiring the necessary information about health conditions or services.
The integration of technology within health began as electronic health (eHealth), the use of electronic platforms for the provision of health information and services, data collection and management, etc. When mobile phones are used to do the same, it is called mobile health (mHealth) [19]. Currently, because of the advent of artificial intelligence (AI) and big data, eHealth and mHealth are now called digital health. Although digital health indicates a much broader and smarter technology horizon, eHealth and mHealth remain the major forms of technology that are being endorsed for system integration to improve health system performance and increase peoples' access to health care [20]. Therefore, there is a growing number of conferences, workshops, websites, apps, and publications regarding how electronic platforms can be implemented and integrated within the health domain [1,2,21-23]. Bangladesh is also in the process of doing the same. Currently, the country has 4 mobile cellular operators and a significant subscription base (149 million). Evidence suggests that a large proportion of households own mobile phones (81\%) [24-28]. The government's commitment to digital development, popularly known as Digital Bangladesh, has helped in fostering strategic and policy direction to adopt ICT in health care (and other development domains) [29-32]. Due to the large subscription base and strong political mandate, there are $\geq 42$ internet-, SMS text messaging-, and call center-based eHealth and mHealth initiatives in the country providing awareness regarding maternal health, drug and alcohol abuse, smoking cessation, HIV/AIDS, and general health care [19,29,33-36]. Despite these initiatives, there is little systematic evidence of the impact of technology on equitable access to health services and information, especially in resource-poor settings such as Bangladesh.

Access to health includes availability, geographic location, affordability, and acceptability (by the community) of services. Considering these dimensions, the challenge is to ensure that everyone, irrespective of their social group, gender, etc, can access the required health care [37]. Bangladesh, despite its successes, has several health system challenges and prevailing health disparities, resulting in limited access to and utilization of quality health care [38,39]. Globally, one of the assumptions of the integration of technology for health care (and other development initiatives) is that digital health can contribute to equitable access to health care, especially in LMICs. However, there is evidence that access to electronic platforms can be hindered because of sociodemographic, gender, and geographic barriers - a state of disparity called the digital divide [40,41]. This divide bears great importance, especially when technology is being endorsed for system integration to improve access to health that can ensure universal health coverage (UHC) in Bangladesh [42]. Considering the growth of ICTs and the proliferation of digital health initiatives, a framework that defines the dimensions of access to health information and services through electronic means can contribute and is crucial to this integration. This is because the rapid growth of ICTs and related development solutions can often be misinterpreted as being equivalent to access and use. 
Figure 1. Mobile-cellular subscription per 100 people by developed, developing, and least developed countries. LDC: least developed country.

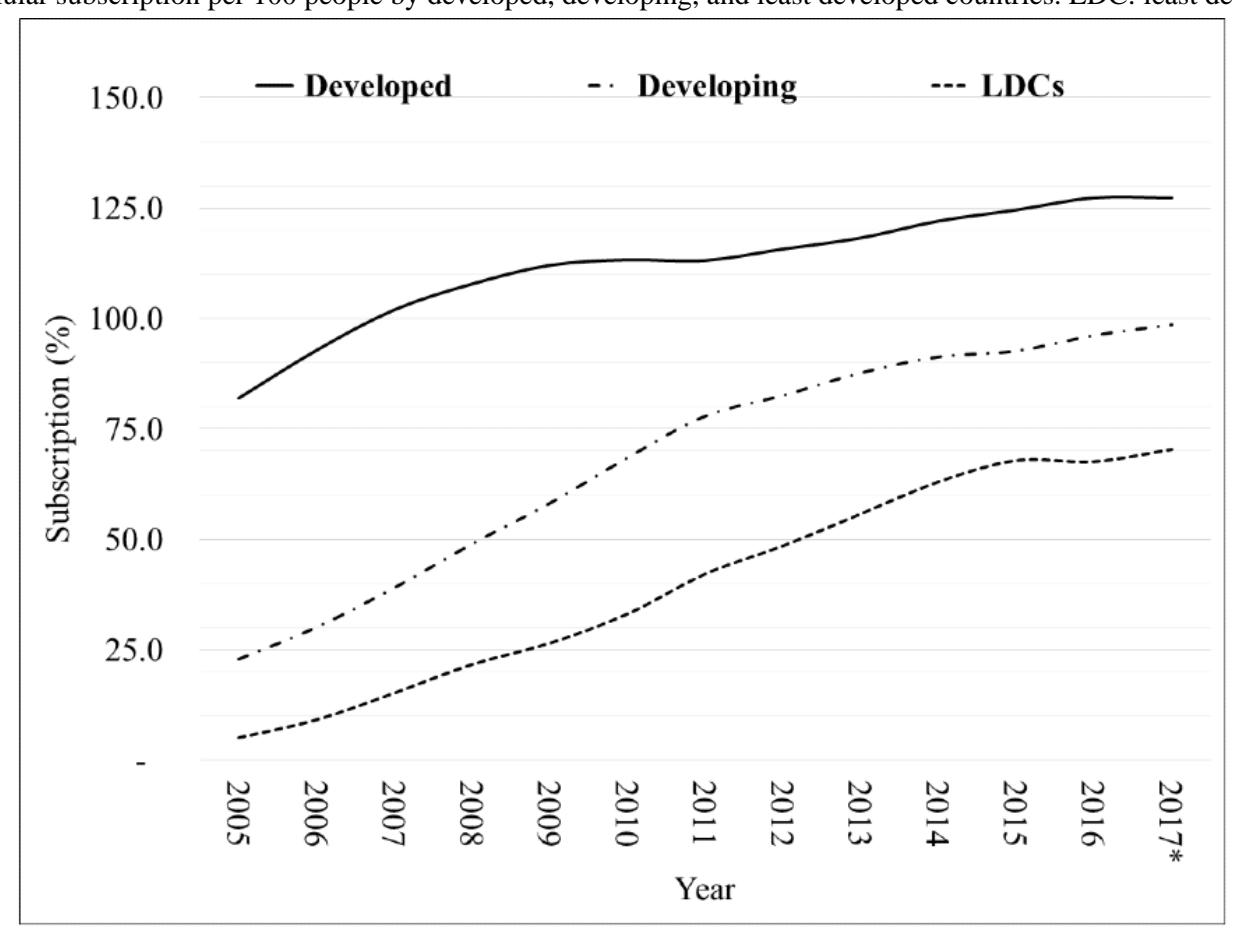

\section{Objective}

This study aims to understand the degree to which ICTs enable Bangladeshi people to increase their access to information and improve their well-being by exploring the factors that influence whether people have access to, and use, digital health information and services (this refers to non-AI-, machine learning-, or big data-based initiatives, previously called eHealth and mHealth). It focuses on who owns electronic devices and uses their device to access health services and/or information and the implications of this for health equity. The findings can be useful in devising a framework to ensure equitable access to digital health information and services in Bangladesh and relevant contexts.

\section{Methods}

\section{Study Setting, Population and Data Collection Tools and Techniques}

The data presented in this paper were collected using a mixed methods design. The quantitative data, supported by research funding from the UK Economic and Social Research Council, comes from a household survey to understand the role of ICTs in health information seeking conducted between October 2013 and February 2014 in a subdistrict of Bangladesh called Mirzapur in the Tangail district. Mirzapur was chosen because it is semiurban with typical sociodemographic characteristics of other such periurban subdistricts in the country [43]. As there were no previous variance estimates of outcome variables, 0.5 was used to calculate the required sample size to obtain $95 \%$ CIs with plus or minus $10 \%$ precision and a design effect of 2 . Thus, a sample size of 2401 was obtained, which finally became 2527 , considering a $5 \%$ nonresponse rate. This was calculated for 3 settings: urban (Dhaka), rural (Chakaria), and semiurban (Mirzapur). Therefore, each setting ended up with a subsample of 842 . In Mirzapur, the sample size reached 854 households. Sample households were selected from 28 villages (30 households per village) using systematic cluster sampling from a Health and Demographic Surveillance System (HDSS) [44]. Approximately $81 \%$ of the information was gathered from the household head or the spouse of the head. Where neither the head nor the spouse was present or able to take part, an adult child of the head or the child's spouse was interviewed. The survey questionnaire was developed and pretested both in Bangla and English (the Bangla version was used to collect actual data) on a browser-based, open-source platform using locally available 7-inch tablets with Android version 4.0. The use of digital means to seek health information or services was explained to the respondents as if the respondent (and/or any member of the household) had heard of or used phones or computers to seek information about any health issues or services via voice call, SMS text messaging, or internet browsing.

To further unpack the survey patterns and findings, 20 focus group discussions (FGDs) were conducted from February to March 2017 as part of the first author's PhD fieldwork. Respondents, who had never used electronic devices to seek health services or information, were selected from 6 FGD groups constructed from the HDSS using typical demographic and economic traits: 8 rich and poor young female and male (college students) groups, 8 rich and poor middle-aged female and male groups, and 4 rich and poor elderly female and male groups.

\section{Data Analysis}

The principal component analysis technique was used to elicit asset scores, and its distribution was arranged in quintiles to create the income groups. The lowest 2 quintiles were grouped as poor, and the highest 2 quintiles were grouped as rich. The distribution of the middle quintile was halved, and the lower half added to the poor group and the upper half to the rich group 
to remove the complexity of constructing the FGD groups. As it was a qualitative exercise, further discussion was conducted with the group during the FGDs to subjectively triangulate the accuracy and related homogeneity of the participants' income status. Each group consisted of 4 to 5 participants, and the discussions took place at locations preferred by the participants, that is, households (for female respondents) and local gathering places (for men). Each session lasted approximately $30 \mathrm{~min}$, facilitated by the first author (male and a PhD student). During discussions, although agreements in opinions were sought, disagreements were also noted along with the respondents' body language. A female notetaker was present during discussions of the female groups. Discussions were conducted and later transcribed in Bangla and then into English for internal consistency.

The sociodemographic analysis was conducted by identifying the frequencies of the respective characteristics/traits. Information on socioeconomic status (SES) was collected from the HDSS as asset scores, a popular method called the asset index. The range of scores was divided into 3 equal categories (lowest as poor, middle, and highest as rich), and frequencies of a sample belonging to the respective categories were identified. The ownership of electronic devices and the use of devices were analyzed for (1) seeking information; (2) health services or information; and (3) demographic factors such as age, gender, education, and income to stratify the results. A quantitative analysis, including tests of significant, was performed using STATA version 14 (made by StataCorp), and Microsoft Excel was used to construct graphs and some amount of data management. The patterns indicated by the quantitative analysis were further explored qualitatively using content analysis techniques [45,46]. Altogether, 3 broad themes emerged: (1) reasons for not using mobile phones or other electronic devices, (2) the extent of awareness of electronic sources of health information, and (3) the role of intermediaries (family members or peers who helped to look for health information using electronic devices). These were analyzed by reference to the gender, SES, and education of respondents. Both analyses were part of $\mathrm{PhD}$ studies supported by the International Development Research Centre.

\section{Ethical Consideration}

Ethical approval was obtained from the institutional review boards of the survey partners: International Centre for Diarrhoeal Disease Research, Bangladesh, and Institute of Development
Studies, University of Sussex (for qualitative data collection). Before data collection, the study was explained to the participants, and written consent or thumbprints were obtained. During data collection (both qualitative and quantitative), informed consent was obtained from all participants.

\section{Results}

\section{Sociemographic Profile of the Respondents and Ownership of Electronic Devices}

Tables 1-3 show the sociodemographic characteristics and ownership of electronic devices of the survey households and respondents. The mean age of the respondents was 41.3 (SD $14.5)$ years, and $67.2 \%(574 / 854)$ of the respondents were between the ages of 25 and 54 years. A total of $38.3 \%$ (327/854) had less than primary education, and a small proportion $(26 / 854$, $3.0 \%)$ were graduates and above. More than half (494/854, $57.9 \%$ ) of the households had 4 to 6 members, representing the usual Bangladeshi family size [47]. In all, 71.9\% (614/854) of the respondents were female. There were more female respondents because the survey was conducted during the daytime when male members were away. A total of $73.1 \%$ $(625 / 854)$ of the respondents were not employed (being a housewife is not considered a job in Bangladesh), which was not intentional. Conversely, $77.3 \%(660 / 854)$ of the household heads were employed. A total of $95.9 \%$ (819/854) of households had a regular income, and $92.6 \%$ (791/854) of households had no social security card (in Bangladesh, having a social security card indicates that the corresponding household belongs to the extremely poor socioeconomic group), a common feature of semiurban Bangladesh. In all, 55.2\% (471/854) of respondents had personal electronic devices and $90.3 \%$ (771/854) of the households owned at least one, which was almost always a mobile phone. The personal ownership was considerably low, perhaps because the survey population had male:female ratio of 1:3 and in a context like Bangladesh, women have less access (in this case ownership) to devices compared with men. However, in the case of household device ownership, family members tend to share electronic devices, and there was always a chance of a lack or less use of devices due to the influence of other family members. Therefore, to understand the equity implications of access to electronic devices, although lower, personal ownership was considered in this study rather than shared ownership. 
Table 1. Demographic statistics of the respondent $(\mathrm{N}=854)$.

\begin{tabular}{|c|c|}
\hline Parameter & Values \\
\hline Age (years), mean (SD) & $41.3(14.5)$ \\
\hline $16-24, \mathrm{n}(\%)$ & $97(11.4)$ \\
\hline $25-34, \mathrm{n}(\%)$ & $215(25.2)$ \\
\hline $35-44, \mathrm{n}(\%)$ & $190(22.3)$ \\
\hline $45-54, \mathrm{n}(\%)$ & $169(19.8)$ \\
\hline $55-64, \mathrm{n}(\%)$ & $110(12.9)$ \\
\hline$>65, \mathrm{n}(\%)$ & $73(8.6)$ \\
\hline \multicolumn{2}{|l|}{ Gender, $\mathbf{n}(\%)$} \\
\hline Male & $240(28.1)$ \\
\hline Female & $614(71.9)$ \\
\hline \multicolumn{2}{|l|}{ Education, n (\%) } \\
\hline Less than primary & $327(38.3)$ \\
\hline Primary & $206(24.1)$ \\
\hline Secondary & $254(29.7)$ \\
\hline Higher secondary & $41(4.8)$ \\
\hline Graduation and above & $26(3.0)$ \\
\hline \multicolumn{2}{|c|}{ Respondent employment status, n (\%) } \\
\hline Yes & $229(26.9)$ \\
\hline No & $625(73.1)$ \\
\hline
\end{tabular}

Table 2. Household-level information of the respondents $(\mathrm{N}=854)$.

\begin{tabular}{|c|c|}
\hline Parameter & Values, $\mathrm{n}(\%)$ \\
\hline \multicolumn{2}{|c|}{ Members per household } \\
\hline $1-3$ & $257(30.1)$ \\
\hline $4-6$ & $494(57.9)$ \\
\hline$>7$ & $103(12.1)$ \\
\hline \multicolumn{2}{|c|}{ Household head working status } \\
\hline Yes & $660(77.3)$ \\
\hline No & $194(22.7)$ \\
\hline \multicolumn{2}{|c|}{ Socioeconomic status of the household } \\
\hline Poor & $295(34.5)$ \\
\hline Middle & $276(32.3)$ \\
\hline Rich & $283(33.1)$ \\
\hline \multicolumn{2}{|c|}{ Presence of menial labor ${ }^{a}$} \\
\hline Yes & $35(4.1)$ \\
\hline No & $819(95.9)$ \\
\hline \multicolumn{2}{|c|}{ Household's social security card } \\
\hline Yes & $61(7.1)$ \\
\hline No & $791(92.6)$ \\
\hline Don't know & $2(0.2)$ \\
\hline
\end{tabular}

${ }^{\mathrm{a}}$ Refers to jobs such as housemaid and unskilled day laborer. 
Table 3. Electronic device ownership of the respondents $(\mathrm{N}=854)$.

\begin{tabular}{lll}
\hline Parameter & Household, $\mathrm{n}(\%)$ & Personal, $\mathrm{n}(\%)$ \\
\hline Ownership of devices & & $471(55.2)$ \\
Total & $771(90.28)$ & $454(53.2)$ \\
Mobile & $751(87.9)$ & $0(0.0)$ \\
Laptop & $2(0.2)$ & $17(2.0)$ \\
Both & $18(2.1)$ & \\
\hline
\end{tabular}

\section{Access to Health-Related Information or Services by Respondents Who Owned Electronic Devices and Influence of Sociodemographic Characteristics}

Tables 4 and 5 show that everyone who owned mobile phones or laptops/computers had used those to communicate or seek information, which included day-to-day conversations to seeking specific services, such as agriculture or other government-related information. It also showed that the predominant means of seeking information was voice calls, followed by SMS text messaging. Analysis of health information seeking for any health concern, including information only, or services showed that of all people who sought health information, a number $(22 / 34$,
$65 \%$ ) reported seeking information/services for minor health issues. Although everyone had used their device to seek some form of information, only $7.2 \%$ (34/471) sought health services or health information.

The use of electronic devices by the people who owned personal devices was stratified by sociodemographic characteristics of age $(P=.02)$, sex $(P=.41)$, education $(P=.004)$, and SES $(P<.01$; Table 6). Although overall use was low, the pattern suggests that among those who used their devices, people who were middle-aged (35 to 54 years), women, and poorer people who had less or no education used them less than others. The difference in use was found to be significant on the chi-square test.

Table 4. Percentage of use and awareness of the use of devices to communicate and seek information by personal device owners (cell phones, laptops, or both; $n=471$ ).

\begin{tabular}{lll}
\hline Parameter $^{\mathrm{a}}$ & Used and aware, $\mathrm{n}(\%)$ & Not used nor aware, $\mathrm{n}(\%)$ \\
\hline Any information & & $0(0.0)$ \\
$\quad$ Total & $471(100.0)$ & $0(0.0)$ \\
Voice call & $471(100.0)$ & $245(52.0)$ \\
SMS text messaging & $226(48.0)$ & $445(94.5)$ \\
$\quad$ Internet & $26(6.0)$ & $437(92.8)$ \\
\hline
\end{tabular}

${ }^{\mathrm{a}}$ Multiple responses.

Table 5. Percentage of communication device use to seek health information $(n=34)$.

\begin{tabular}{ll}
\hline Parameter & Values, $\mathrm{n}(\%)$ \\
\hline Minor health issues & $22(64.7)$ \\
Serious health issues & $12(35.3)$ \\
\hline
\end{tabular}


Table 6. Percentage of personal device owners who sought health information or services by age, sex, education, and socioeconomic status in Mirzapur $(\mathrm{n}=471)$.

\begin{tabular}{|c|c|c|c|}
\hline Parameter & Used and aware, $\mathrm{n}(\%)$ & Not used nor aware, $\mathrm{n}(\%)$ & $P$ value \\
\hline Age in year ${ }^{a}$ & & & .02 \\
\hline Young adult & $5(8.2)$ & $56(91.8)$ & \\
\hline Adult & $15(9.9)$ & $137(90.1)$ & \\
\hline Middle age & $5(2.8)$ & $175(97.2)$ & \\
\hline Elderly and above & $9(11.5)$ & $69(88.5)$ & \\
\hline Gender & & & .41 \\
\hline Male & $13(7.9)$ & $151(92.1)$ & \\
\hline Female & $21(6.8)$ & $286(93.2)$ & \\
\hline Education $^{\mathrm{a}}$ & & & .004 \\
\hline No education & $5(4)$ & $120(96)$ & \\
\hline Primary & $4(3.4)$ & $113(96.6)$ & \\
\hline Secondary & $14(8.4)$ & 153 (91.6) & \\
\hline Higher secondary and above & $11(17.7)$ & $51(82.3)$ & \\
\hline Socioeconomic status ${ }^{\mathrm{a}}$ & & & $<.001$ \\
\hline Poor & $2(1.4)$ & 137 (98.6) & \\
\hline Middle & $8(6)$ & $126(94)$ & \\
\hline Rich & $24(12.1)$ & $174(87.9)$ & \\
\hline
\end{tabular}

${ }^{\text {a }}$ Statistically significant $(P$ value is less than .05$)$.

\section{Barriers to Accessing Health Information and/or Services by the Owners of Electronic Devices}

People who did not use electronic means to access health care or information were further interviewed over FGDs to explore their reasons. Almost everyone has accessed some form of electronic information at some point using mobile phones, mostly through voice calls to an office (ie, local agriculture office or bank) to ask for information. However, despite ample promotion and publicity, the provision of electronic health information or services and the words digital health were unfamiliar to many. One male student mentioned:

I have never heard the word digital health until today. No one told us that one can get health-related information in this way. But sometimes we make calls to some office to know about things. In this way we can get information easily.

Female students had slightly different views. They preferred to call their friends and/or family for information, as one explained:

We use mobile phones to talk about many things. If we need to know about something, we call our friends or elders. But I can't remember if we have ever talked about digital health.

Nonetheless, some of them also use mobile phones to seek health-related information despite a lack of familiarity with formal words such as digital health. Most of the participants had asked for advice from a family member or from someone who had relevant knowledge. As a result, most were reluctant to use electronic means, and only a few had used their device to seek health information, such as the internet and call center. This indicates that people use their phones to ask advice from friends, family, or social acquaintances but are not aware of or do not use formal digital health services. As one of the middle-aged female participants said:

We are ignorant people, we don't understand all these. Besides we don't need this [digital health], it's enough if you can receive and make a call using a phone.

The reasons mentioned in the FGDs for not using electronic means to seek health information and/or services can be summarized into 4 major reasons.

\section{Awareness of Digital Health Services}

Many participants were not aware of eHealth services. This was usual in Bangladesh, given the ongoing promotion of the telecom industry in Bangladesh. A few younger respondents could mention GrameenPhone's health helpline (789), but most of them had a general lack of understanding of eHealth services. Respondents knew that 789 is a service to call physicians using GrameenPhone mobile phones but did not know how it worked. Other than lack of skill to navigate the device and the platform, lack of awareness regarding associated costs and how to talk about personal health ailments was a major concern for the participants.

Most of the participants were confused by the promotional activities undertaken by telecom companies. Mirzapur has an abundance of kiosks and shops that offer a range of mobile 
phone-related services and products with colorful banners and posters displaying information about these services. Considering the overflow of information on display, FGD participants described it as "difficult to distil information related to digital health services." One of the male participants said:

The local shops are full of pictures and words about hundreds of offers. Among those, I don't remember any explaining the availability of such type of health service [digital health]. If we can't find one, how can we be aware that such services exist?

The young and educated participants were more aware of digital health services compared with others. However, even among this group, most did not know much about these services. Some of them were aware of social media-based health initiatives and promotions. Almost everyone had a Facebook account and had seen adverts and information related to health. Although social media (including Facebook) mostly presented information on diet, healthy lifestyles, and beauty tips, some serious issues such as cancer, HIV, and AIDS have also been presented. As one of the female students explained:

We don't know what it is [eHealth] and how can we get health information through it. Or how does it work, how much money it takes etc. Most of us use Facebook or at least have seen it. I sometimes get posts related to beauty or diet-related tips. Sometimes I get information on cancer. But I don't know what eHealth is. I think if digital health services can be made as easy as Facebook, then everyone will come to know about it.

\section{Personal Comfort and Acceptance}

During FGDs, respondents (mostly women) expressed specific concerns regarding not knowing the counselor/provider personally and were hesitant to talk about personal issues and illnesses. One female respondent said:

We are rural ignorant people. How can we talk about illnesses to someone, whom we don't know or see? We are shy and just can't do it.

Middle-aged respondents expressed their lack of trust in the accuracy and quality of digital health information and preferred face-to-face interactions with the person providing the information and advice. Almost everyone preferred to discuss health care needs with their friends and family first, then with local drug sellers and village doctors (quacks) before taking them to formal medical providers. If someone advised them, only then did they consider seeking health information or service electronically. Young and educated respondents were more inclined to use eHealth as they perceived it as ensuring one's confidentiality and privacy. However, they had concerns about cost. A young male participant said:

It takes up money from mobile account balance. Both internet and talk time are expensive. But it's true that you can say many things over a phone which is rather difficult in a face to face consultation with a person whom you know.

\section{Literacy and Skills}

Some participants mentioned that they lacked the skills needed to access digital health effectively. This ranged from proficiency in and with English (and Roman letters) and technical ability to navigate the device and its software (ie, specific app, browser, and internet settings). For example, calling a call center entails the ability to press specific numbers in response to questions or directions. Alternatively, browsing the internet requires English literacy and technical skills to set their devices for internet use. One of the middle-aged participants said:

It's easier for young people. They know how to do this using their mobile phones or computers. They also have the skills to do that. That's why I don't have internet in my phone.

Some young participants also felt that lack of proficiency in English is a barrier to accessing information and services electronically. One of them mentioned:

We are Bengali people and Bangla is our language. We are not very good at English which, in my opinion, is our main problem

Some of the young participants mentioned that family members had asked them (or their friends) to look for health information electronically, but they never looked for it themselves. One of the elderly respondents said:

We are old and that's why we don't know much about
it. We can only receive and make calls. Sometimes if
someone sends an SMS, we take the phone to the other
members of the house to find out what it is. We do the
same when we want to know something about the
phone.

\section{Proximity to Health Facilities}

One of the reasons why respondents did not engage with digital health in Mirzapur was the availability of and access to conventional, formal health services within their vicinity. Mirzapur has a public hospital, the Upazila (subdistrict) Health Complex, and a philanthropic hospital (Kumudini). For any medical emergency, anyone can visit these hospitals instead of using a call center or other digital health services. During discussions, participants agreed that it could be one of the reasons for their reluctance to use digital health services, including information. One of the middle-aged participants mentioned:

Kumudini hospital was established long time ago and is just beside our house. It is much easier and more comfortable for us to visit this hospital when needed. Besides we also have the upazila hospital.

\section{Discussion}

\section{Principal Findings}

This study aims to examine the current linear understanding that access to technology results in access to health care by all. Considering digital health services as a proxy for the integration and implementation of technology for providing health care and information, it has used sociodemographic characteristics to 
explore which population groups have access to technology and have accessed digital health services. In more elaborate terms, it focuses on the degree to which ICT and technology has enabled Bangladeshi people to increase their access to information and improve their well-being by exploring the factors that influence whether people have access to electronic devices (namely, mobile phones or personal computers/laptops) and use these devices to access health services and/or information digitally. The findings show that although there is high household ownership $(771 / 854,90.3 \%)$ of mobile phones, personal ownership is much lower $(471 / 854,55.2 \%)$. Everyone who owned a personal mobile phone used it to seek information and services electronically, but only a small proportion (34/471, $7.2 \%$ ) used it to seek health-related information or services. Although the data suggested younger men and those with a higher education and SES chose to use their devices to access digital health, there was little statistical evidence that sociodemographic factors influenced the use of digital health information and services. According to the findings from the FGDs, nonuse of devices to seek health-related information or services was related to the perception of digital health as an unfamiliar health care-seeking model. Other factors were lack of technological skills and related literacy to seek electronic information or services, associated cost of accessing information, lack of awareness about digital health services, and proximity to functioning health centers.

In the context of rural Bangladesh, previous works have reported slightly lower household ownership of mobile phones, but with an upward trend $[28,31,48]$. The data reported in this paper were collected later, and in a semiurban context (Mirzapur), which is adjacent to Dhaka. Mirzapur is thus likely to have greater access to technology and resources than rural Bangladesh. The high ownership of electronic devices found in this paper is consistent with what others have reported. However, if ownership of devices is used as a proxy for access to digital technology, the data show that only about half of the respondents have personal devices. As there is a dearth of evidence regarding the personal ownership of devices in Bangladesh, it was not possible to compare the findings with the situation in other parts of the country. Nevertheless, the general idea that high household ownership and subscription to mobile-cellular networks means high access to technology needs to be reconsidered and explored further.

\section{Socio-Demography of the Use of Digital Health}

Although this paper has shown that only a small proportion (7.2\%) of owners have used their phones to access digital health for health services or information, in the rural context, use of devices to access digital health has been reported to be even lower (2\%) [28]. The difference in the spread of technology over time and context and related access (semiurban versus rural) can be the reason for this difference. However, such low use of devices generally to access digital health does not indicate that everyone is unable to access services or information digitally. In line with these findings, globally (including Bangladesh), male, young, educated, and wealthier groups are more likely to use their electronic devices to seek general information and health information or services [49-52]. A recently published paper, based on the findings from Mirzapur, reported that the use of mobile phones to access health information at least once in the last 12 months was $45 \%$ in college students (young and educated adults) compared with $18 \%$ in the general population. It also reported that internet users were predominantly (two-third) male phone owners [26]. Therefore, this paper strongly argues that any attempt to integrate technology in the health systems of Bangladesh (and similar contexts) and to endorse related digital health innovations must take into account sociodemographic attributes and the fact that services are more likely to be accessed by young, educated, and male populations. Although this represents a potential disparity in access to digital health, it also positions young and educated people to help the diffusion of technology in the community as change agents and therefore paves the way toward the much discussed and desired integration of technology into the health system to meet the challenges of UHC in Bangladesh and related contexts [42].

\section{Other Factors Influencing the Use of Digital Health}

The other reasons for the low uptake of digital health include lack of awareness about digital health in terms of its modus operandi and availability, lack of personal comfort and acceptance of this form of health service or information, lack of literacy and skill for using digital health technology, and proximity to other health facilities that provide emergency care. However, these reasons are not mutually exclusive, and the relationship within and between them must be examined further in terms of underlying equity challenges. Awareness regarding digital health initiatives is possibly the first and foremost of these reasons, yet communicating the potential of digital health is not, as discussed above, straightforward. Many middle-aged residents have access to household resources and the relevant educational achievements (Table 1) that would make accessing digital health possible, but they are not sufficiently informed and do not have the technological skills (Table 2). They are simultaneously disinclined to pursue health services or information provided in this manner because they are unfamiliar with and do not trust the mode of delivery. Moreover, should they or their family members have a health need, particularly an urgent or emergency one, they would be able to access Mirzapur's other health facilities. Young people, by contrast, are aware of the potential of digital health and have the relevant skills and literary sophistication required (Table 1). As indicated by others, they do not have the material resources and influence that would support and facilitate access to digital health (ie, financial resources and decision-making capacity in health care need) [26]. As a result, they tend to use this service when, as shown above, older people who have the necessary resources request that young people engage with digital health services or information. Young people, like the older generations, have access to Mirzapur health facilities when there is an emergency; however, their primary health concerns are, as others have reported and the earlier discussion indicates, private, nonurgent, and often deemed unnecessary, such that their concerns are dismissed and they are treated with disrespect [26].

The importance of sociodemographic and economic factors and related material factors was highlighted in other technology-based health interventions in Bangladesh. One of the popular mHealth interventions in Bangladesh called 
Aponjon, supported by the United States Agency for International Development and implemented in 2012, was designed to provide voice or text message-based pregnancy and newborn care. After studying the impact of the intervention, it was concluded that exposure to Aponjon messages was not associated with improved maternal and child health outcomes, such as the presence of skilled birth attendance at birth, breast-feeding practices, or facility delivery. Rather, higher sociodemographic and income status of the mother was more significantly associated with reported improvements [53]. Another intervention study was piloted to understand the feasibility and acceptability of a mobile phone-based intervention that combined counseling and the payment of cash transfers to improve the perception of both maternal nutrition during pregnancy and nutrition of the infant in rural Bangladesh. Although the study could not conclude the intervention as effective, it highlighted other material issues such as charging the mobile phone or spending cash (obtained from the project) to feed one's family rather than focusing on the nutrition of the pregnant mother or infant as major barriers to the effectiveness of such mHealth interventions [54].

\section{Conclusions}

There is high awareness and use of electronic devices to access electronic information and/or services across various sociodemographic categories in Bangladesh. Global trends suggest that access to the use of mobile phones and computers is expanding, including contexts like Bangladesh [15,31]. However, Mirzapur's respondents continued to avoid digital health initiatives. Why? The only paper that has tried to explain the reason for such low use in Bangladesh concluded that, although the community has some technological readiness and will to use mHealth, lack of adequate human resources and technological abilities of the people may have restricted the use of electronic devices for health services or information [55].

Inequitable access to health care is one of the major health system concerns for LMICs, including Bangladesh. Expansion of coverage of health care provision and implementing efficient policy making and governance activities is critical for improving population access to health care. At the same time, adopting an equity focus can ensure the inclusion of various population groups. The central question in this paper is, therefore, does high access to technology mean that various sociodemographic groups can access digital health services, thereby having higher access to health care and information? The answer lies in how technology interfaces with other social determinants of health to produce equity and inequity. Shankardass et al [56] argued that health inequities are caused by complex social, economic, and political factors (ie, the influence of gatekeepers, affordability of services, provision of quality health care, and strategies to secure access of poor and vulnerable groups to health). These factors limit recognition of the need for and creation of proequity policies. Digital health promises to address access to health services and information [57], and, in demonstrating substantial growth in technological access, it gives the impression that challenges in access to health services and information are being addressed, leading to a decrease in the digital divide. However, as shown in this paper, this approach of ubiquitous access to technology obscures how inequity in access to health plays out. As Embrett and Randall [58] argue, addressing health inequity is dependent on generating public awareness to develop sufficient political incentives for change. However, the lack of access to health services and health information that, for instance, young people experience is not socially acknowledged. Digital health information and services offer some potential to address this challenge, with young people having appropriate awareness, sufficient skills, education, and literacy that would make this an attractive option, but they lack the English sophistication required to articulate health needs and use, and they do not have the necessary resources to turn this into a reality. Addressing inequity in digital health requires action to increase not only device ownership and the technical skills necessary to operate these devices but also the material resources to encourage their use and social recognition of health needs and inequity.

This paper presents evidence on the implications of the adoption of digital health services on equitable access to health. To capitalize on the growth of technology, it is important to recognize that without appropriate recognition, digital health services may result in underused services and can influence further disparities such as information-rich poor groups. This means that without the required approach, whereas some social groups will have more access to health care because of their better health, technology, and general literacy, others may become vulnerable and marginalized with restricted access. This should serve as a basis for any future attempt in devising (and adopting) operational frameworks that envision both accountability and equity for effective integration of ICT platforms (digital health) to address disparities and related health systems challenges for Bangladesh and other LMICs.

\section{Limitations of the Study}

This survey was undertaken with the expectation of high levels of digital health usage. As a result, insufficient attention was paid to the use of mobile phones for health information through casual conversations among peers and kin.

\section{Acknowledgments}

This research has been funded by the ESRC/DFID Poverty Alleviation Scheme, grant number ES/J018651/1. International Centre for Diarrhoeal Disease Research, Bangladesh (icddr,b) acknowledges with gratitude the commitment of DFID and the ESRC (UK) to its research efforts. icddr,b is also grateful to the Governments of Bangladesh, Canada, Sweden and the UK for providing core/unrestricted support. The authors also gratefully acknowledge the support of Tamanna Sharmin, Nazib uz Zaman Khan, Mohammad Selim and other members from the icddr,b team for various phases of data collection, management and analysis of the data. We would like to thank Drs. Simon Batchelor and Nigel Scott for their contributions to the survey. Finally, we would like to thank the International Development Research Centre (IDRC), Canada for partially funding the PhD which produced this paper. 


\section{Conflicts of Interest}

None declared.

\section{References}

1. Lewis T, Synowiec C, Lagomarsino G, Schweitzer J. E-health in low- and middle-income countries: findings from the center for health market innovations. Bull World Health Organ 2012 May 1;90(5):332-340 [FREE Full text] [doi: 10.2471/BLT.11.099820] [Medline: 22589566]

2. mHealth New Horizons for Health Through Mobile Technologies. World Health Orgnaization. 2011. URL: http://www. who.int/about/ [accessed 2018-04-26]

3. Statistics. ITU: Committed to Connecting the World. 2018 Nov 13. URL: https://www.itu.int/en/ITU-D/Statistics/Pages/ default.aspx [accessed 2020-06-08]

4. ICT Facts \& Figures. ITU: Committed to Connecting the World. 2019 Jan 13. URL: https://www.itu.int/en/ITU-D/Statistics/ Documents/facts/ICTFactsFigures2015.pdf [accessed 2020-06-08]

5. Minges M. Exploring the Relationship Between Broadband and Economic Growth. The World Bank. 2016. URL: http:/ /documents.worldbank.org/curated/en/178701467988875888/pdf/ 102955-WP-Box394845B-PUBLIC-WDR16-BP-Exploring-the-Relationship-between-Broadband-and-Economic-Growth-Minges. pdf [accessed 2018-04-25]

6. Katz R. Impact of Broadband On the Economy: Research to Date and Policy Issues. ITU: Committed to Connecting the World. 2012. URL: https://www.itu.int/ITU-D/treg/broadband/ITU-BB-Reports Impact-of-Broadband-on-the-Economy. pdf [accessed 2018-04-25]

7. The Mobile Economy. GSMA. 2015. URL: https://www.gsma.com/mobileeconomy/global/2015/ GSMA Global Mobile Economy Report 2015.pdf [accessed 2018-04-25]

8. Comparing Agent-Led versus Self-Register Subscription Models for mAgri Services: Mobile for Development. GSMA. 2018. URL: https://www.gsma.com/mobilefordevelopment/programme/magri/ comparing-agent-led-versus-self-register-subscription-models-magri-services/ [accessed 2018-04-25]

9. Case Study: Airtel Green SIM. GSMA. 2015. URL: https://www.gsma.com/mobilefordevelopment/wp-content/uploads/ 2015/03/GSMA Case IKSL web2.pdf [accessed 2018-04-25]

10. de Wulf L. Tradenet in Ghana Best Practice of the Use of Information Technology. The World Bank. 2004. URL: http:/ /documents.worldbank.org/curated/en/137601468771018721/pdf/313620GH0trade11WDR20050bkgd0paper1.pdf [accessed 2018-04-25]

11. Company Profile. bKash. 2017. URL: https://www.bkash.com/about/company-profile [accessed 2018-04-26]

12. Quadir K. The Story of bKash. The Daily Star. 2015. URL: https://www.thedailystar.net/the-story-of-bkash-21235 [accessed 2018-04-26]

13. About Vodafone Group. Vodafone Group. 2019 Jan 13. URL: http://www.vodafone.com/content/index/about/about-us/ money transfer.html [accessed 2020-06-08]

14. Camner G, Pulver C, Sjöblom E. What Makes a Successful Mobile Money Implementation? Learnings from M-PESA in Kenya and Tanzania. GSMA. 2009. URL: https://www.gsma.com/mobilefordevelopment/wp-content/uploads/2012/06/ mpesa case study9983.pdf [accessed 2018-04-25]

15. Aker JC, Mbiti IM. Mobile phones and economic development in Africa. J Econ Perspect 2010 Aug 1;24(3):207-232. [doi: 10.1257/jep.24.3.207]

16. Khalil M, Dongier P, D'Costa V, Zhen-Wei QC, Smith P, Sudan R. Information and Communications for Development: Extending Reach and Increasing Impact. The World Bank. 2009. URL: http://documents.worldbank.org/curated/en/ 645821468337815208/pdf/487910PUB0EPI1101Official0Use0Only1.pdf [accessed 2018-04-26]

17. Connecting to Work: How ICTs Are Expanding Job Opportunities Worldwide. The World Bank. 2013. URL: http://www. worldbank.org/en/news/feature/2013/09/10/how-icts-are-expanding-job-opportunities [accessed 2018-04-26]

18. Raftree L. ICT Opportunities and Barriers for Youth in Developing Countries. UNICEF Office of Research - Innocenti. 2018. URL: https://www.unicef-irc.org/article/1009-ict-opportunities-and-barriers-for-youth-in-developing-countries.html [accessed 2018-04-26]

19. Ahmed T, Lucas H, Khan AS, Islam R, Bhuiya A, Iqbal M. eHealth and mhealth initiatives in Bangladesh: a scoping study. BMC Health Serv Res 2014 Jun 16;14:260 [FREE Full text] [doi: 10.1186/1472-6963-14-260] [Medline: 24934164]

20. Beratarrechea A, Lee AG, Willner JM, Jahangir E, Ciapponi A, Rubinstein A. The impact of mobile health interventions on chronic disease outcomes in developing countries: a systematic review. Telemed J E Health 2014 Jan;20(1):75-82 [FREE Full text] [doi: 10.1089/tmj.2012.0328] [Medline: 24205809]

21. Akter S, Ray P. mHealth - an ultimate platform to serve the unserved. Yearb Med Inform 2010;19(1):94-100. [Medline: 20938579]

22. Ryu S. Book review: mhealth: new horizons for health through mobile technologies: based on the findings of the second global survey on ehealth (global observatory for ehealth series, volume 3). Healthc Inform Res 2012;18(3):231 [FREE Full text] [doi: 10.4258/hir.2012.18.3.231] 
23. Chetley A, Davies J, Trude B, Mcconnell H, Ramirez R, Shields T, et al, editors. Improving Health, Connecting People : the Role of ICTs in the Health Sector of Developing Countries - A Framework Paper. Washington, DC: World Bank; 2006.

24. Mobile Phone Subscribers in Bangladesh February, 2018. BTRC: Bangladesh Telecommunication Regulatory. 2018. URL: http://www.btrc.gov.bd/content/mobile-phone-subscribers-bangladesh-february-2018 [accessed 2018-04-26]

25. Ahmed T, Bloom G, Iqbal M, Lucas H, Rasheed S, Waldman L. E-health and M-Health in Bangladesh: Opportunities and Challenges Internet. Evidence Report No. 60; Horizon Scanning (Tomorrow Today). Brighton: Institute of Development Studies; 2014.

26. Waldman L, Ahmed T, Scott N, Akter S, Standing H, Rasheed S. 'We have the internet in our hands': Bangladeshi college students' use of ICTs for health information. Global Health 2018 Mar 20;14(1):31 [FREE Full text] [doi: 10.1186/s12992-018-0349-6] [Medline: 29554929]

27. Paina L, Wilkinson A, Tetui M, Ekirapa-Kiracho E, Barman D, Ahmed T, et al. Using theories of change to inform implementation of health systems research and innovation: experiences of future health systems consortium partners in Bangladesh, India and Uganda. Health Res Policy Syst 2017 Dec 28;15(Suppl 2):109 [FREE Full text] [doi: 10.1186/s12961-017-0272-y] [Medline: 29297374]

28. Khatun F, Hanifi S, Iqbal M, Rasheed S, Rahman MS, Ahmed T, et al. Prospects of mhealth services in Bangladesh: recent evidence from Chakaria. PLoS One 2014;9(11):e111413 [FREE Full text] [doi: 10.1371/journal.pone.0111413] [Medline: 25375255]

29. Our eHealth: The Roadmap of Impressive Development. DGHS. 2012. URL: http://www.dghs.gov.bd/licts file/images/ eHealth/our_eHealth_Aug_2012.pdf [accessed 2020-06-23]

30. The Millennium Development Goals: Bangladesh Progress Report 2011. Planipolis - UNESCO. 2012. URL: http://planipolis. iiep.unesco.org/upload/Bangladesh/Bangladesh MDG 2011.pdf [accessed 2020-06-23]

31. Country Overview: Bangladesh. GSMA Intelligence. 2014. URL: https://www.gsmaintelligence.com/research/ ?file=140820-bangladesh.pdf\&download [accessed 2018-04-26]

32. National ICT Policy - 2009. Ministry of Science and Information \& Communication Technology, Government of the People's Republic of Bangladesh. 2009. URL: http://www.bcs.org.bd/img/upload/page/11.pdf [accessed 2014-12-01]

33. Afroz T. Delivery of Mobile Phone Aided Health Services in Rural Bangladesh: A Study on Two Upazilas Internet. Master in Public Policy and Governance (MPPG). 2012. URL: http://mppg-nsu.org/attachments/396 13 [accessed 2020-06-23]

34. Ansari N. Stories from rural Bangladesh: presenting impact of the mobile phone based 'health help line' service in rural Bangladesh. In: Svensson J, Wicander G, editors. The 2nd International Conference on M4D Mobile Communication Technology for Development. Kampala, Uganda: Karlstad University Studies; 2010.

35. Bangladesh eHealth Inventory Report. -: Bangladesh Knowledge Management Initiative (BKMI); 2014.

36. Uddin J, Biswas T, Adhikary G, Ali W, Alam N, Palit R, et al. Impact of mobile phone-based technology to improve health, population and nutrition services in rural Bangladesh: a study protocol. BMC Med Inform Decis Mak 2017 Jul 6;17(1):101 [FREE Full text] [doi: 10.1186/s12911-017-0502-9] [Medline: 28683742]

37. Peters DH, Garg A, Bloom G, Walker DG, Brieger WR, Rahman MH. Poverty and access to health care in developing countries. Ann N Y Acad Sci 2008;1136:161-171. [doi: 10.1196/annals.1425.011] [Medline: 17954679]

38. Ahmed S, Hossain M, Rajachowdhury AM, Bhuiya A. The health workforce crisis in Bangladesh: shortage, inappropriate skill-mix and inequitable distribution. Hum Resour Health 2011 Jan 22;9:3 [FREE Full text] [doi: 10.1186/1478-4491-9-3] [Medline: 21255446$]$

39. Chowdhury AM, Bhuiya A, Chowdhury ME, Rasheed S, Hussain Z, Chen LC. The Bangladesh paradox: exceptional health achievement despite economic poverty. Lancet 2013 Nov 23;382(9906):1734-1745. [doi: 10.1016/S0140-6736(13)62148-0] [Medline: 24268002]

40. Understanding the Digital Divide. Paris, France: Organisation for Economic Co-Operation and Development (OECD); 2001.

41. Wilhelm A. myth. Inf Soc 2002 Oct;18(5):415-416. [doi: 10.1080/01972240290108212]

42. Adams AM, Ahmed T, El Arifeen S, Evans TG, Huda T, Reichenbach L, Lancet Bangladesh Team. Innovation for universal health coverage in Bangladesh: a call to action. Lancet 2013 Dec 21;382(9910):2104-2111. [doi: 10.1016/S0140-6736(13)62150-9] [Medline: 24268605]

43. Mirzapur Upazila. Banglapedia. 2015. URL: http://en.banglapedia.org/index.php?title=Mirzapur_Upazila [accessed 2018-04-30]

44. Das S, Nasrin D, Ahmed S, Wu Y, Ferdous F, Farzana F, et al. Health care-seeking behavior for childhood diarrhea in Mirzapur, rural Bangladesh. Am J Trop Med Hyg 2013 Jul;89(1 Suppl):62-68 [FREE Full text] [doi: 10.4269/ajtmh.13-0107] [Medline: 23629937]

45. Krippendorff K. Content Analysis: an Introduction to Its Methodology. Thousand Oaks, CA: Sage Publications; 2004.

46. Mayring P. Qualitative Content Analysis. Forum Qualitative Sozialforschung. 2000. URL: http://www.qualitative-research.net/ index.php/fqs/article/view/1089/2385\#gcit [accessed 2018-04-30]

47. Bangladesh Demographic and Health Survey 2014. The DHS Program. 2014. URL: https://dhsprogram.com/pubs/pdf/ FR311/FR311.pdf [accessed 2020-06-23] 
48. Tran MC, Labrique AB, Mehra S, Ali H, Shaikh S, Mitra M, et al. Analyzing the mobile 'digital divide': changing determinants of household phone ownership over time in rural Bangladesh. JMIR Mhealth Uhealth 2015 Feb 25;3(1):e24 [FREE Full text] [doi: 10.2196/mhealth.3663] [Medline: 25720457]

49. Shah R, Jaisinghani P. Toward a More Inclusive Digital Economy. MIT Press Journals. 2014. URL: https://www. mitpressjournals.org/userimages/ContentEditor/1421439266694/INNOVATIONS-DIGITAL-INCLUSION-FOREWORD. pdf [accessed 2018-05-08]

50. Ac'lar A. Exploring the Aspects of Digital Divide in a Developing Country. Issues in Informing Science and Information Technology. 2011. URL: http://iisit.org/Vol8/IISITv8p231-244Acilar248.pdf [accessed 2018-05-08]

51. Bridging the Gender Gap: Mobile Access and Usage in Lowand Middle-income Countries. GSMA. 2015. URL: https:/ /www.gsma.com/mobilefordevelopment/wp-content/uploads/2016/02/Connected-Women-Gender-Gap.pdf [accessed 2020-06-23]

52. Khan NU, Rasheed S, Sharmin T, Ahmed T, Mahmood SS, Khatun F, et al. Experience of using mhealth to link village doctors with physicians: lessons from Chakaria, Bangladesh. BMC Med Inform Decis Mak 2015 Aug 5;15:62 [FREE Full text] [doi: 10.1186/s12911-015-0188-9] [Medline: 26242574]

53. Alam M, D'Este C, Banwell C, Lokuge K. The impact of mobile phone based messages on maternal and child healthcare behaviour: a retrospective cross-sectional survey in Bangladesh. BMC Health Serv Res 2017 Jun 24;17(1):434 [FREE Full text] [doi: 10.1186/s12913-017-2361-6] [Medline: 28645278]

54. Huda TM, Alam A, Tahsina T, Hasan MM, Khan J, Rahman MM, et al. Mobile-based nutrition counseling and unconditional cash transfers for improving maternal and child nutrition in Bangladesh: pilot study. JMIR Mhealth Uhealth 2018 Jul 18;6(7):e156 [FREE Full text] [doi: 10.2196/mhealth.8832] [Medline: 30021707]

55. Khatun F, Heywood AE, Ray PK, Hanifi S, Bhuiya A, Liaw S. Determinants of readiness to adopt mhealth in a rural community of Bangladesh. Int J Med Inform 2015 Oct;84(10):847-856. [doi: 10.1016/j.ijmedinf.2015.06.008] [Medline: 26194141]

56. Shankardass K, Lofters A, Kirst M, Quiñonez C. Public awareness of income-related health inequalities in Ontario, Canada. Int J Equity Health 2012 May 21;11:26 [FREE Full text] [doi: 10.1186/1475-9276-11-26] [Medline: 22613058]

57. Phua KH, Sheikh K, Tang S, Lin V. Editorial - health systems of Asia: equity, governance and social impact. Soc Sci Med 2015 Nov;145:141-144. [doi: 10.1016/j.socscimed.2015.10.027] [Medline: 26522185]

58. Embrett MG, Randall G. Social determinants of health and health equity policy research: exploring the use, misuse, and nonuse of policy analysis theory. Soc Sci Med 2014 May;108:147-155. [doi: 10.1016/j.socscimed.2014.03.004] [Medline: 24641879]

\author{
Abbreviations \\ AI: artificial intelligence \\ FGD: focus group discussion \\ HDSS: Health and Demographic Surveillance System \\ ICT: information and communications technology \\ LDC: least developed country \\ LMIC: low- and middle-income country \\ SES: socioeconomic status \\ UHC: universal health coverage
}

Edited by G Eysenbach; submitted 02.10.19; peer-reviewed by H Lucas, MAB Siddique, B Ghose, T Tahsina; comments to author
26.11.19; revised version received 29.02.20; accepted 29.02.20; published 21.07.20
Please cite as:
Ahmed T, Rizvi SJR, Rasheed S, Iqbal M, Bhuiya A, Standing H, Bloom G, Waldman L
Digital Health and Inequalities in Access to Health Services in Bangladesh: Mixed Methods Study
JMIR Mhealth Uhealth 2020;8(7):e16473
URL: $\underline{\text { http://mhealth.jmir.org/2020/7/e16473/ }}$
doi: $\underline{10.2196 / 16473}$
PMID: $\underline{32706736}$

(C)Tanvir Ahmed, Syed Jafar Raza Rizvi, Sabrina Rasheed, Mohammad Iqbal, Abbas Bhuiya, Hilary Standing, Gerald Bloom, Linda Waldman. Originally published in JMIR mHealth and uHealth (http://mhealth.jmir.org), 21.07.2020. This is an open-access article distributed under the terms of the Creative Commons Attribution License (https://creativecommons.org/licenses/by/4.0/), which permits unrestricted use, distribution, and reproduction in any medium, provided the original work, first published in JMIR 
mHealth and uHealth, is properly cited. The complete bibliographic information, a link to the original publication on http://mhealth.jmir.org/, as well as this copyright and license information must be included. 